\title{
Internalization of Pancasila Value at SMP Islam Plus at Thohari Tuntang Semarang Regency Indonesia
}

\author{
Giri Harto Wiratomo ${ }^{1, *}$ Suprayogi ${ }^{2}$ Natal Kristiono ${ }^{3}$
}

\author{
${ }^{1}$ Politic and Citizenship Departement, Universitas Negeri Semarang \\ ${ }^{2}$ Politic and Citizenship Departement, Universitas Negeri Semarang \\ ${ }^{3}$ Politic and Citizenship Departement, Universitas Negeri Semarang \\ *Email: girihw@mail.unnes.ac.id
}

\begin{abstract}
Pancasila values need to be loved and instilled in citizens. Pancasila is the ideology of Indonesian citizens. As an ideology, of course it is not only in the abstraction aspect but needs to be realized. Since reformation, the internalization of Pancasila values has strengthened to be revitalized again. The internalization of Pancasila values can be identified by strengthening character education programs and coupled with the Pancasila student program. This research is located at SMP Islam Plus At Tohari Tuntang Semarang Regency. The reason for choosing this school is this school strengthens the values of Pancasila, namely SMP Islam Plus At Thohari Tuntang, Semarang Regency Indonesia. This school has the advantage of being an Islamic-based school that combines public schools and tradisional islamic boarding schools. The purpose of this study was to analyze the internalization of Pancasila values through the Pancasila student program at SMP Islam Plus At Thohari Tuntang, Semarang Regency. The research method used is qualitative. The approach used is a case study. Retrieval of data using interviews, documentation, and observation. The result of this research is that the internalization of Pancasila values in schools is carried out through habituation, exemplary and repetition. Religious materials support efforts to internalization Pancasila values.
\end{abstract}

\section{Keywords: Internalization, Pancasila, Moral Values, Character.}

\section{INTRODUCTION}

Since the reformation era in Indonesia in 1998, the Indonesia society is not familiar with Pancasila. Not knowing this is due to the stigma of some of the some views that Pancasila is a product of the New Order. Pancasila is Indonesia state and ideology Indonesia people. In New Order called P4 courses (upgrading course on directives for the realizing and implementation of Pancasila).[1] The public is now more towards a view of the euphoria of democracy. This freedom leads to freedom that is as free as possible. As a state based on the foundation of the state Pancasila. Soekarno called Pancasila a philosopiche grondslag. Coupled with the influence of globalization currents that alienate young citizens from the nation's culture. Meanwhile, according to predictions in 2045, Indonesia will get a demographic bonus. Pancasila is expected to be able to answer the challenges of the times.

The public has recently been shocked by the problem of the relationship between religion and Pancasila. Such as terrorism, intolerance, islamophobia and radicalism. There is a stigma that religion is the source of acts of terror. Religion has been accused of teaching violence to young citizens. Meanwhile, other parties claim that religion never teaches to bad behavior. Because personal actions should not be associated with religion. Young citizens are able to implement the values of Pancasila as a way of life. Some of these views of life contain values that are considered good and want to be applied in all areas of life. Therefore, it is inevitable that Pancasila will function in every element of institutions, education, culture and organizations in Indonesia. For example in schools which later collaborated with pesantren. Pesantren is the oldest islamic education in Indonesia. It is tradisional islamic education in Indonesia. In the pesantren, the islamic religious sciences are taught. Today Pancasila is still being contested, as if Pancasila has not yet found a bright spot in the hearts of its own people. Pancasila is still being debated by many groups including the Muslim community in Indonesia. As if Pancasila is not the right basis for the majority of Muslims.

Based on the description above, with various data and facts, if a school that combines Islamic boarding schools makes efforts to internalization the values of Pancasila in student life, students not only appear to have their identities as religious people, but also their national 
identity is increasingly clear. Practicing Pancasila is a manifestation of Islam. Student obedience, such as what is Pancasila, becomes a reflection of students as good citizens. With this, Pancasila as a representation of Islam is not in doubt. One method of character education is through the internalization of values. One of the internalization of Pancasila values to the young generation from an early age is in formal schools. Each school has its own characteristics, such as SMP Islam Plus At Thohari Tuntang, Semarang Regency, which is a character-based school and implements a boarding school. This study aims to explore the internalization of Pancasila values in schools. The uniqueness of this research is to explore the internalization of Pancasila values in schools that integrate Islamic boarding schools.

Based on the problems that have been described, this article formulates a problem, namely how to internalization the values of Pancasila in SMP Islam Plus At Tohari Tuntang, Semarang Regency and what are the supporting and inhibiting factors for the internalization of Pancasila values at SMP Islam Plus At Tohari Tuntang, Semarang Regency.

\section{METHOD}

The research method used is qualitative. The approach used in this research is a case study. The case study was chosen because the researcher wanted to photograph a particular problem on the research object. The location of this research is at SMP Islam Plus At Tohari Tuntang, Semarang Regency. The data sources of this research are field and literature data. Field data in the form of observations and interviews with informants. The data collection process was carried out through four data collection techniques, namely: observation, interview, documentation study and literature study. Data analysis in qualitative research consists of three activities carried out simultaneously, namely: data reduction, data presentation, and conclusion /verification. [2]

\section{RESULT AND DISCUSSION}

SMP Islam Plus At Tohari Tuntang is located in Semarang Regency, central java, Indonesia. This school was formed in 2017. The school is under the guidance of the At Tohari foundation. This school has 12 teachers. The school has a vision of the school, namely the creation of a generation that is smart, skilled, tough, loves the country and has a good character. This school uses the 2013 curriculum. The vision of a school that loves the homeland and has a strong character, shows that there is a harmony between nationalist and religious values. In addition, this school provides learning of the yellow book at Islamic boarding schools. This school integrates the curricula of public schools and pesantren. This school emphasizes plus character in its students. Schools add religious aspects to students through education in Islamic boarding schools. SMP Islam Plus At Tohari Tuntang has several excellent programs, namely the Kitab Kuning, english lessons, and science.

Islamic boarding schools are traditional Islamic educational institutions to study, understand, live and practice Islamic teachings by emphasizing the importance of religious morals as guidelines for daily behavior.[3] In the morning until noon, students study in public schools then in the afternoon until evening recite Al Quran at the pesantren. The model of the education system in this school uses a boarding school. All students live in a dormitory, with separate male and female dormitories. The pesantren is located in the same complex as the school building. In Islamic boarding schools students have a different calling, namely santri. This school is called Islam Plus because students in addition to general lessons are also given religious lessons, especially in Islamic boarding schools. The subjects taught in Islamic boarding schools are for example the science of hadith, monotheism, figh, morals, and the interpretation of Al Quran. All these subjects are developed in the pesantren with the aim of students becoming knowledgeable people, especially in the field of religious knowledge and having a high personality, character and social spirit.

Schools not only prepare cognitively, but also affectively in the form of religious values. In addition, they can also learn about politics and law through learning in public schools. The pesantren is a place for them to get knowledge and religious teachings from an ulama or kiai. In its teaching practice, islamic boarding schools have a concept of teaching Islam based on the Al Quran and hadith, as well as Islamic books such as Safinah, Taklimu Mutaallim, and other books which are the work of Islamic leaders. The Taklimu Mutaallim book provides lessons about the manners of a student while studying. Pesantren is an educational institution that is under the leadership of one or several kiailulama and is assisted by a senior santri and several family members. The pesantren in this school has the wing ahlusunah wal jamaah adhered to by Nahdlatul Ulama (NU). Through the pesantren, Pancasila values are instilled in the level of religious values and love for the country.

As is known, there are two religious mass organizations in Indonesia, namely NU and Muhammadiyah. Muslims as the majority power have a big responsibility to make Indonesia a good country with a merciful god (baldatun thayyibatun wa rabbun 
ghafur). NU uses the wasathiyah principle in accepting the national state. The principle of wasathiyah or Islamic moderation is that there is monotheism as a fundamental Islamic teaching and at the same time it maintains a balance in the creation and unity of all circles of human consciousness. The ukhuwah trilogy is ukhuwah islamiyah, ukhuwah basariyah, and ukhuwah wathoniyah (muslim brotherhood, human brotherhood, and national and state brotherhood). Meanwhile, Muhammadiyah uses the principle of the national state as darul ahdi wa syahadah. Principle darul ahdi wa syahadah, namely the Pancasila state is understood as the state ideology resulting from the consensus of all elements of the nation (dar al-ahdi) and at the same time as a place of evidence or testimony (dar al-syahadah) to create a safe and peaceful country (dar al-salam). Religion is a manifestation of sincerity. The character that is expected to emerge is moral glory.

The internalization of Pancasila values at SMP Islam Plus At Tohari Tuntang is packaged in learning activities. Learning activities in planting values through intracurricular, extracurricular, and co-curricular activities.[4] First, intraculricular activities are activities that are listed in the curriculum. The curriculum used in schools is the 2013 curriculum. Intracurricular activities, namely the values of Pancasila are instilled through the subjects of Pancasila and Civics Education whose time allocation is three hours of lessons per week. Every material in civics education implicit the value of Pancasila. The internalization of Pancasila values cannot be separated from the PPKn subject matter. The example before starting the lesson, begin with prayer. By praying, students will have religious values. In addition, the PPKn material in class VIII semester one is taught about the values of Pancasila. Second, extracurricular activities, namely through scouts and flag raising officer (paskibra).

Third, co-curricular activities, internalization Pancasila values are carried out by carrying out habituations in the form of a flag ceremony every Monday, celebrating national holidays, habituation of Asmaul Husna before starting lessons, habituating greetings and greetings when meeting with the teachers and teachers. Internalization the value of discipline through enforcing rules, enforcing class picket schedules, and giving examples of honest, friendly and polite characters by teachers to students. A habit is behavior that repeated regularly or a usual way of behaving.[5] Meanwhile, role models generally tend to imitate / imitate the teacher. As taught to respect leaders and love the country. Activities in Islamic boarding schools such as routine activities must pray fardu in congregation, deliberation activities in solving lesson problems or general problems outside of lessons. In addition, we must obey the rules by not being late in participating in activities at the pesantren, namely respecting punctuality, building independent awareness, maintaining cleanliness of the environment with cleanliness pickets, voluntary work once a week, helping each other, respecting, respecting each other, and not permitting. berating each other. All of these are forms of the role of the pesantren in instilling the habituation of the practice of Pancasila values. For example, planting Pancasila values in the yellow book which teaches about respecting leaders and loving the country. Loving the motherland is one of the third precepts.

\subsection{Pancasila Students}

Ministery of Education and Culture in 2021 issued a Pancasila student policy. Pancasila students are the embodiment of Indonesian students as lifelong students who have global competence and behave in accordance with the values of Pancasila, with six main characteristics: having faith, being devoted to God Almighty, and having noble character, global diversity, mutual cooperation, independence, critical reasoning, and creative.[6] The six characteristics are described as follows:

1. Believe in God Almighty and have morality

Indonesian students who believe in God Almighty and have morality are students who have morals in their relationship with God Almighty. He understands his religious teachings and beliefs and applies this understanding in his daily life. There are five key elements of believing, being devoted to God Almighty, and having good morals: (a) religious morals; (b) personal character; (c) morals towards humans; (d) morals to nature; and (e) national character. The internalization of these values in schools is very strong by adding a religious character through Islamic boarding schools. Programs at schools and Islamic boarding schools, for example, include the obligatory prayers for five times in congregation, sunna prayers, reading the $\mathrm{Al}$ Quran, reading the nadham, and participating in istigasah activities.

2. Global diversity

Indonesian students maintain their noble culture, locality and identity, and remain open-minded in interacting with other cultures, so as to foster a sense of mutual respect and the possibility of forming them with a positive noble culture and not contradicting the noble culture of the nation. The elements and keys of global diversity include knowing and respecting culture, intercultural communication skills in interacting with others, and reflection and responsibility for the experience of diversity. Internalization these values is like deliberation outside of subject matter in schools and Islamic boarding schools. 
3. Working together

Indonesian students have the ability to work together, which is the ability to voluntarily carry out activities together so that the activities carried out can run smoothly, easily and lightly. The elements of mutual cooperation are collaboration, caring and sharing. Activities at school such as awareness in obeying the rules at the pesantren, helping each other, mutual cooperation, studying actively, maintaining cleanliness, politeness, obedience, love for the country, and participating in flag ceremonies.

4. Independent

Indonesian students are independent students, namely students who are responsible for the process and learning outcomes. The key elements of independence consist of self-awareness and the situation at hand and self-regulation. The internalization of Pancasila values in schools such as being honest, fair, independent, getting along, tolerating, not being late for class, being diligent in studying, dressing neatly, maintaining politeness, respecting teachers, obeying teachers, not defaming academics or institutions, not violating what are the school and pesantren regulations.

5. Reason critically

Students who reason critically are able to objectively process information both qualitatively and quantitatively, build linkages between various information, analyze information, evaluate and conclude it. The elements of critical reasoning are obtaining and processing information and ideas, analyzing and evaluating reasoning, reflecting on thoughts and thought processes, and making decisions. Activities at school such as class discussions and questions and answers while studying books at Islamic boarding schools.

6. Creative

Creative students are able to modify and produce something original, meaningful, useful, and impactful. The key element of being creative consists of generating original ideas and producing original works and actions. Internalization Pancasila values is like making new things so that students are not bored and bored in learning.

\subsection{Supporting and Inhibiting Factors}

The internalization of Pancasila values in schools is effective if supported by all parties. The implementation of the planting is influenced by supporting and inhibiting factors. Supporting factors are divided into internal and external supporting factors. Internal supporting factors consist of the enthusiasm and work ethic of the teacher in overseeing the internalization of Pancasila values very well and students are very open in carrying out the values of Pancasila which are packaged in various activities. External supporting factors consisting of the surrounding environment strongly support the application of Pancasila values in schools, including student guardians, school committees, foundations, and the community, even local government officials. One example of the involvement of the local government is the involvement of schools in various community activities in the surrounding areas such as social services, celebrations for the independence of the Republic of Indonesia, celebrations of national and religious holidays. Even in 2018 there was a nationalism development from the Salatiga City education office.

Inhibiting factors consist of internal and external inhibiting factors. The internal inhibiting factor is the lack of adequate facilities and infrastructure in schools that support the habituation of internalization Pancasila values. The school is currently in the process of developing an Islamic boarding school. In addition, various student characters influence this activity of internalization the character of Pancasila habituation. The various characters of students are influenced by family and environment. Family parenting is different from one another. The external inhibiting factor, namely the covid-19 pandemic, has become a separate obstacle in the application of the internalization of Pancasila values. the variety of national activities that need to involve outsiders is limited. Judging from the vision of the school, it is listed as creating students who love the country. One way to love the homeland by instilling Pancasila values in the lives of students in Islamic boarding schools has two aspects.

\section{CONCLUSION}

The internalization of Pancasila values at SMP Islam Plus At Tohari Tuntang Semarang Regency is well systemed. Schools have the opportunity to instill Pancasila values by having an integrated system between public schools and Islamic boarding schools. With various problems in the relationship between state and religion, this school produces students who have a strong foundation of Pancasila values, because they are manifested in belief in God through Islamic boarding school learning.

\section{ACKNOWLEDGMENTS}

This research was support by Faculty of Social Science. Thank you very much for SMP Islam Plus At Tohari Tuntang Semarang Regency.

\section{REFERENCES}

[1] Morfit, Michael. Pancasila: The Indonesian State Ideology According To The New Order Government. Asian Survey Vol. 21. No. 8 (Aug., 1981). pp 838-851. University of California Press (1981). 
[2] Creswell, J. W. Reseach Design, Pendekatan Kualitatif, Kuantitatif, Dan Mixed. Yogyakarta: Pustaka Pelajar (2010).

[3] Hendri, dkk. Penanaman Nilai-Nilai Pancasila Pada Kehidupan Santri Di Pondok Pesantren. Jurnal Civics: Media Kajian Kewarganegaraan Vol. 15 No. 2. pp 103-110 (2018).

[4] Wiratomo, Giri Harto, dkk. Model Internalisasi Nilai-Nilai Pancasila Oleh Guru PPKn Jenjang SMP Di Kota Semarang. Jurnal Integralistik No.2/Th. XXVIII/2017, Juli-Desember 2017 (2017).

[5] Mahmud. Pendidikan Karakter Konsep dan Implementasi. Bandung: Alfabeta. pp 93 (2012).

[6] Rencana Strategi Nasional Kementerian Pendidikan dan Kebudayaan (2020). 